траєкторії старшокласника, і потребує наявності цілеспрямованої, організованої системи профорієнтаційної роботи. Проте, нині вона ще має безсистемний, епізодичний, іноді формальний характер. Тому систематичне використання різноманітних форм та методів профорієнтаційної роботи має здійснюватися за спільних зусиль школи, сім’ї та ВНЗ.

Перспективу подальших досліджень убачаємо у визначенні педагогічних умов формування професійної спрямованості старшокласників.

\title{
Література
}

1. Адаменко О. В. Проблеми диференційованого i профільного навчання у вітчизняній педагогіці другої половини XX століття / О.В.Адаменко // Наук. зап. Сер. Педагогіка і психологія / Вінниц. держ. пед. ун-т ім. М. Коцюбинського. Вінниця, 2004. - № 11. - С. 68-72. 2. Браташ О. Проблеми і розвиток вищої гірничої освіти [Електронний ресурс]/ О. Браташ. - Режим доступу: http://ea.dgtu.donetsk.ua:8080/jspui/ bitstream/ 123456789/ 7279/1 3. Коломісць М. Проблема підготовки класного керівника до організації профорієнтаційної роботи / М. Коломієць // Проблеми підготовки сучасного вчителя: наук.-метод. зб. - Умань, 2013. - № 7. - С. 176-182. 4. Концепція державної системи професійної орієнтації населення [Електронний ресурс].- Режим доступу: http://zakon4.rada.gov.ua/laws/show/842-2008 5. Мантуленко С. В. Формування готовності майбутніх учителів географії до профільного навчання старшокласників: дис. ... канд. пед. наук: 13.00.04 / Світлана Вікторівна Мантуленко. - Кривий Ріг, 2014. - 253 с. 6. Побірченко Н. А. Організаційно-психологічні умови професійної орієнтації в загальноосвітній школі / Н. А. Побірченко, І. Б. Марченко // Проблеми сучасної психології: зб. наук. праць К-ПНУ імені Івана Огієнка, Інститут психології ім. Г. С. Костюка АПН України - 2009. - Вип. 6.- Ч. 2. - С. 175-185. 7. Положення про професійну орієнтацію молоді, яка навчається // Інформаційний збірник Міністерства освіти України. - К. 1995. - № 15. - С. 2-7. 8. Професія. Кар’єра. Успіх / [Авториупоряд. : Лях Т. Л., Малієнко Ю. М., Троценко Н. Є., Цюман Т. П., Шеламкова А. М.]; за ред. Т. П. Цюман. - К. : Основа-Принт, 2010. - 132 с. 9. Профільне навчання в старшій школі: шляхи розвитку: [наук.-доп. бібліогр. покажч.]. Вип.1/ АПН України. ДНПБ України ім. В. О. Сухомлинського; уклад.: Л. О. Пономаренко, Л. І. Ніколюк, Л. І. Самчук, I. М. Каневська [Електронний ресурс]. - К., 2004. - 163 с. - Режим доступу: http://www.dnpb.gov.ua/ datas/upload/files/320849870.pdf

УДК 373.55.016:91

Ірина Варфоломеєва

\section{ОРГАНІЗАЦІЯ НАВЧАЛЬНО-ВИРОБНИЧОЇ ПРАКТИКИ У КЛАСАХ ГЕОГРАФІЧНОГО ПРОФІЛЮ}

Варфоломєєва I. М. Організація навчально-виробничої практики $\quad$ у класах географічного профілю.

У статті подано теоретичне обгрунтування проведення літньої навчальної практики з географії в умовах старшої профільної школи та методичні рекомендації $з$ удосконалення і впровадження у практику теоретичних основ іiі організації у 10 класах географічного профілю.

Ключові слова: профільне навчання, навчально-виробнича практика, географічний профіль, педагогічна практика, географія.

Варфоломеева I. М. Организация учебно-производственной практики в классах географического профиля. 
В статье представлено теоретическое обоснование проведения летней учебной практики по географии в условиях старшей профильной школы и методические рекомендации по усовершенствованию и внедрению в практику теоретических основ ее организации в 10 классах географического профиля.

Ключевые слова: профильное обучение, учебно-производственная практика, географический профиль, педагогическая практика, география.

Varfolomeyeva I. M. Organization of field internsip in grades of geography specialization.

The article theoretically substantiates summer geography internship in the context of senior profession-oriented school aswell as methodical recommendations concerning improvement and put into practice theoretical bases of its organization in the $10^{\text {th }}$ grade of geography specialization.

Key words: subject-oriented training, field internship, geography specialization, pedagogical practice, geography.

Старша профільна школа покликана на основі диференційованого навчання здійснювати підготовку учнів до свідомого визначення напрямку своєї професійної діяльності, оволодіння низкою предметів на поглибленому рівні, підготовку до продовження навчання у ВНЗ. У зв’язку з цим актуалізується питання добору методів, форм і засобів навчання в класах географічного профілю. Особливого значення набуває проблема організації літньої навчальної практики з географії, що є важливим складником профільного навчання.

Аналіз методичної літератури засвідчив, що питанню реалізації практичної спрямованості навчання природничо-математичних дисциплін присвячено значну кількість праць. У більшості досліджень із питань організації і проведення практик у шкільному курсі географії (І. Баринова, М. Зінкевич, С. Кобернік, В. Корнєєв, Г. Щукіна [4]) вони визначаються як важливий компонент шкільної географічної освіти. Під час іiі проведення учні набувають практичних умінь та навичок, використовують набуті теоретичні знання на практиці, працюють із різноманітними джерелами інформації. Більшість фахівців уважає, що літня навчальна практика може розглядатись як форма організації навчальної діяльності учнів, спрямована на застосування, поглиблення й закріплення теоретичних знань, а також на отримання нових у поєднанні з формування, розвитком і закріпленням необхідних для цього вмінь і навичок.

Згідно з листом МОН України №1/9-97 «Про порядок проведення екскурсій і навчальної практики учнів загальноосвітніх навчальних закладів» від 07.03.2001 р. у середніх школах проводяться навчальні екскурсії та навчальна практика з базових дисциплін [5].

Meта статmі полягає в теоретичному обгрунтуванні проведення літньої навчальної практики з географії в умовах старшої профільної школи та методичному удосконаленні і впровадженні у практику теоретичних основ іiі організації у 10 класах географічного профілю.

Теоретико-методична основа проведення навчальної практики з географії нами представлена у вигляді узагальненої моделі (рис 1). Наведена модель відображає зв’язки між метою, визначеними за ії допомогою принципами, завданнями й етапами проведення та змістом географічної практики. Зміст навчальної практики визначає особливості управлінської діяльності вчителя, визначення видів занять методів їх проведення. 


\section{НАВЧАЛЬНА ПРАКТИКА 3 ГЕОГРАФІЇ}

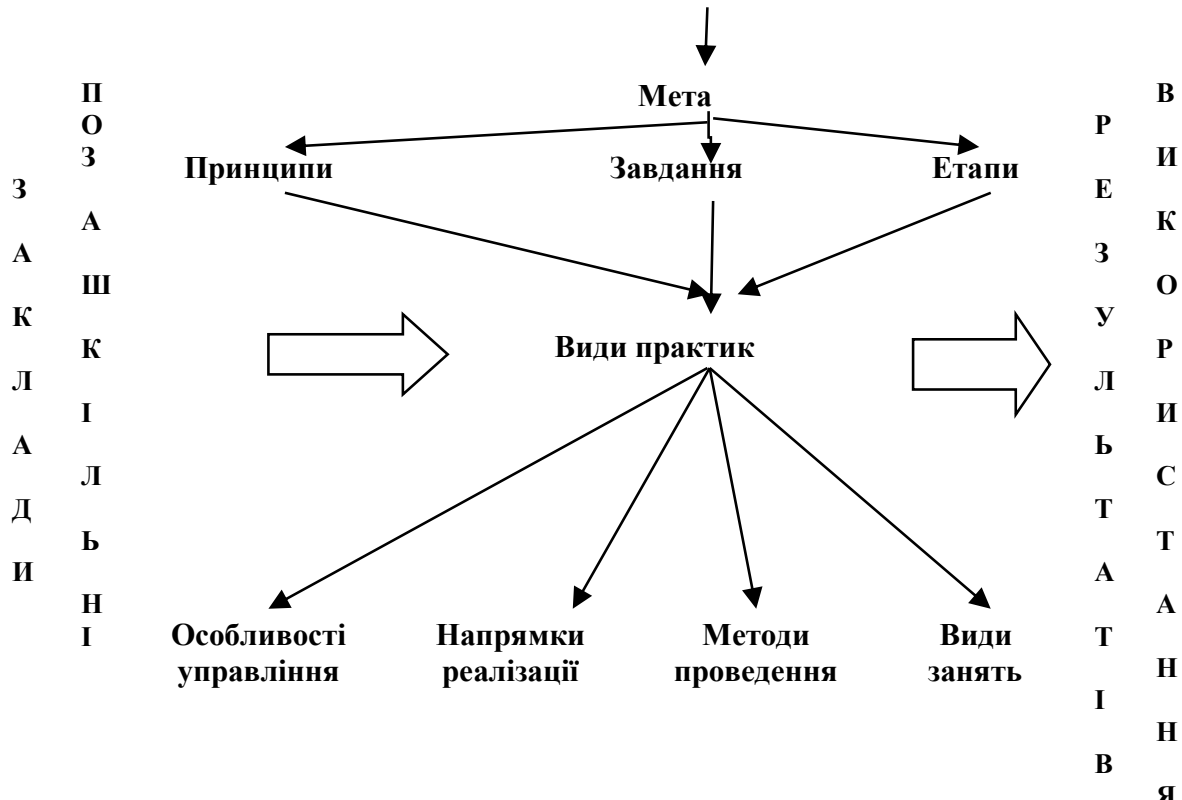

Рис. 1. Модель організації навчальної практики з географії

Головною метою проведення навчальної практики в основній та старшій школі $€$ розвиток пізнавальної діяльності учнів, залучення їх до пошукової роботи, поглиблення та систематизацію знань, умінь учнів, усвідомлення практичної складової навчальних курсів, формування міжпредметних зв'язків тощо.

Можна виокремити принципи, відповідно до яких будується вся робота під час практики: краєзнавчий підхід, єдності теоретичних основ навчання практичної значимості отриманих знань i наявність інтересу у групи учнів i ïx керівника, самостійність, ініціатива, творча активність учнів.

Головними завданнями з навчальної практики з географії є:

- формування в учнів навичок самостійної творчої діяльності 3 географії у позаурочний час;

- поглиблення й розширення знань, здобутих безпосередньо на уроках географії та інших природничих наук;

- розвиток пізнавальних інтересів учнів, розширення їхнього світогляду, підвищення загальної культури;

- виховання любові до рідного краю, своєї Батьківщини, бережливого ставлення до природи, всього навколишнього середовища;

- зацікавлення учнів безпосередньою участю у збереженні, відновленні та примноженні багатств Батьківщини, їх охороні та раціональному використанні;

- закладання основ фізичного та психічного здоров'я, загартовування учнів під час поєднання навчальної практики з туризмом, змаганнями з орієнтування тощо.

Дослідивши сучасні методичні рекомендації, щодо проведення навчальної практики з географії, було встановлено, що попри їх видову різноманітність, відсутня 
класифікація. Тому ми запропонували власну класифікацію. Пропонуємо виокремлювати такі види навчальної географічної практики:

1. Предметно-тематичні:

- фізико-географічні (гідрологічні, метеорологічні, геоморфологічні, геологічні тощо);

- економіко-географічні (етнографічні, виробничі на промисловому чи сільськогосподарському підприємстві, ознайомлення 3 рекреаційними об'єктами тощо).

2. Комплексні:

- комплексні фізико-географічні та економіко-географічні;

- краєзнавчі;

- туристичні;

- екологічні тощо.

У процесі проведеня практики вчителі можуть використовувати досвід і матеріальну базу позашкільних закладів освіти, станцій юних туристів, натуралістів, гуртків і секцій центрів творчості учнів. Поєднання можливості школи та закладів позашкільної освіти може мати досить значний ефект.

Години, відведені на навчальну практику, за рекомендаціями Міністерства освіти i науки, можна використовувати задля реалізації практичної частини навчальних програм предметів навчального плану, зокрема - проведення комплексних практикумів 3 географії, практичних занять на місцевості, конструювання приладів та обладнання кабінету географії, занять на навчальнодослідних ділянках і географічному майданчику тощо. На заняттях учні залучаються до роботи 3 різноманітними об'єктами: лабораторним та демонстраційним обладнанням, природними об'єктами, різноманітною навчальною та довідковою літературою, наочністю (таблиці, карти, атласи, колекції тощо), комп'ютерами, пошуковими системами (каталоги, мережа Інтернет) тощо. Це надає можливість учням використовувати набуті знання й уміння задля пошуку розв'язання проблем у змінній ситуації, бачити нові можливості застосування об'єктів, підвищити вмотивованість навчання, розвинути навички самостійної роботи. Такі види навчальної діяльності оцінюються обов'язково.

Методика проведення навчальної практики передбачає такі етапи:

1. Підготовчий, під час якого учні ознайомлюються 3 метою та формами проведення навчальної практики, дізнаються про місце проведення практики, отримують завдання та вимоги щодо подання результатів проведеної роботи, інструктуються 3 правил техніки безпеки, отримують необхідні прилади й обладнання, ознайомлюються зі способами фіксації дослідження, ведення польового щоденника.

2. Змістово-організаційний, під час якого відбувається навчальна діяльність, що передбачена планом проходження практики, учні виконують завдання працюють у групах або індивідуально.

3. Підсумковий, під час якого проводиться звітування учнів щодо проведеної роботи, оформлюються результати дослідження (виставки, газети, колекції), перевірка набутих знань і вмінь, підбиття підсумків навчальної практики.

На наш погляд, доцільно виокремити деякі особливості організації такого виду навчально-пізнавальної діяльності учнів, як навчальна практика: формування життєвих і предметних компетенцій, занятість усіх учнів, орієнтація на інтегрованість і системність знань і умінь, iї комплексний характер і поєднання процедури цінування 
й оцінювання.

Форми організації навчальної практики можуть бути різними залежно від іiі змісту, постійного чи тимчасового характеру роботи, матеріально-технічного оснащення, віку, підготовки учнів, кліматичних та інших особливостей. До них можна віднести такі види занять: курси за вибором, практикуми, комплексні заняття міжпредметного характеру, конкурси та змагання, заняття за інтерактивними методиками, презентації науково-дослідних проектів, наукові конференції, екскурсії, експедиції.

Результати навчальної практики з географії бажано узагальнювати, щоб їх можна було використати під час проведення навчальних занять та у виховному процесі 3 усіма учнями школи. Ці результати оформлюються та експонуються у краєзнавчих куточках і музеях школи, кабінеті географії, використовуються в процесі підготовки дидактичних посібників.

Як уже зазначалось, ми вважаємо за необхідне виокремити дві групи навчальних практик у класах географічного профілю: предметно-тематичні і комплексні. До комплексних, на нашу думку, можна віднести практики, що мають комплексну мету, передбачають використання загальногеографічних знань і формування відповідних умінь. На нашу думку, до таких практик необхідно віднести комплексну фізикогеографічну, комплексну економіко-географічну, краєзнавчу, туристичну й екологічну практики.

Розглянемо особливості проведення деяких 3 них. Планування діяльності учнів в період краєзнавчої практики подано у табл. 1.

Таблиия 1

Планування краєзнавчої навчальної практики

\begin{tabular}{|c|c|c|c|}
\hline \begin{tabular}{|c|}
$\begin{array}{c}\text { Етап навчальної } \\
\text { практики }\end{array}$ \\
\end{tabular} & Тема заняття & Форма проведення & \begin{tabular}{|c|} 
К-ть \\
годин
\end{tabular} \\
\hline 1. Підготовчий & \multicolumn{2}{|l|}{ Настановча конференція } & 2 \\
\hline \multirow[t]{7}{*}{$\begin{array}{l}\text { 2. Змістово- } \\
\text { організаційний }\end{array}$} & $\begin{array}{l}\text { Виявлення взаємозв'язків } \\
\text { окремих елементів } \\
\text { природи в географічному } \\
\text { ландшафті. }\end{array}$ & $\begin{array}{l}\text { Дослідження природного } \\
\text { комплексу (яр, балка, річкова } \\
\text { долина, степ, ліс, парк) }\end{array}$ & 5 \\
\hline & $\begin{array}{l}\text { Вплив людської діяльності } \\
\text { на процеси видозміни } \\
\text { природного середовища. }\end{array}$ & $\begin{array}{l}\text { Експедиція до антропогенного } \\
\text { комплексу: сміттєзвалище, сад, } \\
\text { селитебельний ландшафт }\end{array}$ & 5 \\
\hline & $\begin{array}{l}\text { Вплив людської діяльності } \\
\text { на процеси видозміни } \\
\text { природного середовища. }\end{array}$ & Звіти результатів експедиції & 2 \\
\hline & $\begin{array}{l}\text { Антропогенні ландшафти } \\
\text { рідного краю }\end{array}$ & $\begin{array}{l}\text { Презентації науково-дослідних } \\
\text { проектів }\end{array}$ & 1 \\
\hline & $\begin{array}{l}\text { Вивчення процесів } \\
\text { видозміни рельєфу, який } \\
\text { здійснюється на очах } \\
\text { людини і частково під їі } \\
\text { впливом. }\end{array}$ & Наукова конференція & 2 \\
\hline & $\begin{array}{l}\text { Дослідження географії } \\
\text { населення рідного краю. }\end{array}$ & $\begin{array}{l}\text { Практикум з вирішення задач } 3 \\
\text { теми «Населення» }\end{array}$ & 2 \\
\hline & $\begin{array}{l}\text { Дослідження географії } \\
\text { власного населеного }\end{array}$ & $\begin{array}{l}\text { Конкурс проектів } \\
\text { «Туристичними маршрутами }\end{array}$ & 1 \\
\hline
\end{tabular}




\begin{tabular}{|c|c|c|c|}
\hline $\begin{array}{c}\begin{array}{c}\text { Етап навчальної } \\
\text { практики }\end{array} \\
\end{array}$ & Тема заняття & Форма проведення & \begin{tabular}{|c|} 
К-ть \\
годин \\
\end{tabular} \\
\hline & пункту. & рідного краю» & \\
\hline & $\begin{array}{l}\text { Дослідження географії } \\
\text { власного населеного } \\
\text { пункту. }\end{array}$ & $\begin{array}{l}\text { Екскурсія до краєзнавчого } \\
\text { музею }\end{array}$ & 2 \\
\hline & $\begin{array}{l}\text { Вивчення окремих } \\
\text { виробництв. }\end{array}$ & $\begin{array}{l}\text { Екскурсія до металургійного } \\
\text { підприємства }\end{array}$ & 5 \\
\hline & $\begin{array}{l}\text { Вивчення окремих } \\
\text { виробництв. }\end{array}$ & $\begin{array}{l}\text { Екскурсія до машинобудівного } \\
\text { підприємства }\end{array}$ & 5 \\
\hline & $\begin{array}{l}\text { Вивчення окремих } \\
\text { виробництв. }\end{array}$ & $\begin{array}{l}\text { Екскурсія до підприємства } \\
\text { легкої промисловості }\end{array}$ & 5 \\
\hline & $\begin{array}{l}\text { Вивчення окремих } \\
\text { виробництв. }\end{array}$ & $\begin{array}{l}\text { Екскурсія до } \\
\text { сільськогосподарського } \\
\text { підприємства }\end{array}$ & 5 \\
\hline & $\begin{array}{l}\text { Складання фізико- } \\
\text { географічних і економіко- } \\
\text { географічних карт своєї } \\
\text { місцевості. }\end{array}$ & $\begin{array}{l}\text { Інтегроване заняття } 3 \\
\text { інформатикою }\end{array}$ & 5 \\
\hline 3. Підсумковий & $\begin{array}{l}\text { Комплексний опис } \\
\text { географічної } \\
\text { характеристики міста }\end{array}$ & Звітна конференція & 3 \\
\hline \multicolumn{3}{|l|}{ Усього } & 50 \\
\hline
\end{tabular}

Розглянемо кожен етап практики детальніше. Перший етап - підготовчий. Для його реалізації ми пропонуємо використати таку форму проведення, як настановча конференція. На цій конференції вчитель має повідомити учням основну мету й завдання навчальної практики, форми iii проведення, а також форму звіту, який повинні надати учні після завершення навчальної практики 3 фізики. На цій конференції необхідно поділити учнів класу на групи по 4-5 осіб у кожній. Можна надати можливість учням самостійно обирати членів своєї групи, оскільки від комфортності під час спілкування залежить успіх їхньої спільної діяльності.

Наступний етап навчальної практики - змістово-організаційний. Це основний етап, на проведення якого відводиться значна частина часу, запланованого на практику. Під час цього етапу учні виконують завдання, які запропонував учитель. Проміжний контроль діяльності учнів можна провести у формі виставки фізичних приладів і звіту наукових груп.

Для навчальної практики ми рекомендуємо обрати такі теми: виявлення взаємозв'язків окремих елементів природи у географічному ландшафті, вплив людської діяльності на процеси видозміни природного середовища, вивчення процесів видозміни рельєфу, який здійснюється на очах людини і частково під іiі впливом, дослідження географії населення і населених пунктів, вивчення окремих виробництв, складання фізико-географічних і економіко-географічних карт своєї місцевості, комплексний опис географічної характеристики міста. Такий вибір обумовлено тим, що школярі вже знайомі з основними поняттями цих розділів, а використання означених тем під час практики надає їм можливість поглибити i систематизувати свої знання, переконатися в їхній практичній значущості, а також створює умови для розвитку предметної компетенції, знайомства 3 природними і антропогенними комплексами своєї місцевості. Важливою формою проведення 
навчальної практики може бути навчально-дослідницька діяльність. Цей вид діяльності характеризується тим, що вона спрямована на виконання дослідницьких завдань, яка передбачає пошук і пояснення закономірних зв'язків та відношень експериментально спостережуваних фактів, явищ, процесів, шляхом застосування прийомів та наукових методів пізнання. У результаті такої роботи учні активно оволодівають знаннями, знайомляться 3 методологією географічної науки. У них відбувається розвиток дослідницьких умінь і навичок, формування пізнавальних мотивів та організаційних якостей. Приклади завдань, які можуть виконати учні: 1) визначення особливостей грунтового профілю, складу грунту; 2) визначення видового складу рослин в певному природно-територіальному комплексі; 3) спостереження за станом погоди; 4) вимірювання ширини, глибини, швидкості течії води в річці; 5) розрахунки витрати і річного стоку води в річці.

Однією 3 форм організації навчальної практики можуть бути екскурсії на виробництво, у природу, до краєзнавчого музею. Ми пропонуємо провести екскурсії на тему: «Міттал стіл - флагман металургійної промисловості України», «Пол Стар спільне підприємство в легкій промисловості», «Розведення страусів - екзотичний напрям птахівництва для України». Головне завдання таких екскурсій - розширити і поглибити знання 3 питань: галузева структура господарства, типи підприємств, особливості технологічних процесів, фактори що впливають на розміщення, зв'язки. Проведені екскурсії сприяють оволодінню учнями умінь: планувати і проводити спостереження на виробництві; оформляти результати спостережень і дослідів у формі звіту, таблиць, схем. Такі екскурсії сприяють розвитку особистості через: формування інтелектуальних і практичних умінь, набуття досвіду пізнавальної діяльності; виховання моральних якостей учнів під час спілкування між собою. Екскурсія до музею має на меті ознайомлення з експозиціями музею: «Природа», «ІІторія», «Етнографія». Після закінчення екскурсіі, учні готують звіт, у якому відображають відповіді на всі завдання, поставлені перед ними.

Ще один вид можливої діяльності учнів під час навчальної практики - це розв'язування задач. Цей вид діяльності сприяє удосконаленню умінь і навичок учнів розв'язувати географічної задачі, переконує учнів у наявності зв'язку між теорією i практикою.

Важливими, на нашу думку, повинні стати й інші види навчально-пізнавальної діяльності учнів: участь у науковий конференції, захист проектів, виготовлення електронних презентацій, використання електронних карт i космічних знімків, складання власних карт. Такі форми організації практики сприятимуть підвищенню пізнавального інтересу учнів до предмету, розвитку їхніх комунікативних здібностей, Завершальний етап навчальної практики - підсумковий. Ми пропонуємо його провести у формі підсумкової конференції, на якій школярі підводять підсумки своєї діяльності. Конференцію необхідно провести у піднесеному настрої, запросити адміністрацію школи, вчителів 3 інших предметів і учнів 3 інших класів. На конференції бажано продемонструвати виготовлені прилади, результати навчальнодослідницької діяльності, презентації проектів.

Як бачимо, комплексна навчальна практика 3 географії у 10 класі географічного профілю наповнена різноманітними формами проведення, що сприяє узагальненню, систематизації, поглибленню знань школярів, а також їх зацікавленню до вивчення цієї науки.

Задля реалізації завдань загальної середньої освіти щодо посилення практичної спрямованості навчально-виховного процесу, професійно-орієнтаційної роботи 3 учнями, підготовки їх до активної трудової діяльності, залучення до суспільно 
корисної праці можливе проведення предметно-тематичної практики у класах географічного профілю. Як уже зазначалось їх можна поділити на фізико-географічні: гідрологічні, метеорологічні, геоморфологічні, геологічні й економіко-географічні: етнографічні, виробничі на промисловому чи сільськогосподарському підприємстві, знайомство $з$ рекреаційними об'єктами. Визначення загальної теми такої практики залежить від інтересів учнів, керівника практики, місцевими можливостями та потребами.

Особливу увагу під час їх організації, на нашу думку, необхідно приділяти використанню таких форм роботи, як краєзнавчі пошуки, робота в органах місцевого самоврядування, місцевих підприємствах та установах, відділах виконкому, науководослідних установах, музеях тощо. Навчальну практику такого виду може проводитись і під час навчального року.

Задля організації економіко-географічної навчально-виробничої практики можливе укладання відповідних угод із підприємствами, організаціями, установами. До читання профільних спецкурсів, проведення бесід, зустрічей, профорієнтаційної роботи можуть бути залучені спеціалісти вищих навчальних закладів та установ.

Проведене нами дослідження 3 теми надало змогу встановити, що навчальна практика $\epsilon$ обов'язковими та необхідними складниками навчально-виховного процесу. Її проведення передбачає створення умов для наближення змісту навчальних предметів до реального життя, спостереження та дослідження учнями явищ природи і процесів життєдіяльності суспільства, розширення світогляду учнів, формування в них життєво необхідних компетенцій, посилення практичної i професійноорієнтаційної спрямованості навчально-виховного процесу.

\section{Література}

1. Бібік Н. М. Проблема профільного навчання в педагогічній теорії і практиці. Профільне навчання: Теорія і практика / Н. М. Бібік // Зб. наук. праць за матеріалами методолог. Семінару АПН України. К. : Пед.преса, 2006. - С. 23-29. 2. Гільберт Т. Профільне навчання географії/ Т. Гільберт - Краєзнавство. Географія. Туризм. 2010 р. - № 46. - С. 5-6. 3. Кобернік С. Г. Методика викладання географії в школі: [навч.-метод. посіб.] / $\quad$ С. Г. Кобернік. $-\quad$ К. : $\quad$ Стафед-2, 2000. - $\quad$ С. $42-44$. 4. Корнєєв В. П. Особливості вивчення географії в старшій профільній школі / В. П. Корнєєв, О. В. Корнеев, Л. І. Круглик // Географія - 2008. - № 17-40-й внесок. 5. Лист МОН України № 1/9-97 «Про порядок проведення екскурсій і навчальної практики учнів загальноосвітніх навчальних закладів» від 07.03.2001 [Електронний ресурс]. 6. Профільне навчання: теорія і практика/ (П. І. Замаскіна, В. І. Кизенко, Л. А. Липова, В. В. Малишев та ін.): [під ред. Л. А. Липової]. - К. : ВВП «Компас», 2007. -192 c.

$$
\text { УДК 6(07)+159.928 }
$$

\section{Лілія Крутченко}

\section{РОЛЬ ХУДОЖНЬОГО КОНСТРУЮВАННЯ В РОЗВИТКУ ТВОРЧИХ ЗДІБНОСТЕЙ УЧНІВ}

Крутченко Л. В. Роль художнього конструювання в розвитку творчих здібностей учнів.

У статті розкрито психолого-педагогічні основи творчої діяльності учнів загальноосвітньої школи, а також обгрунтовано можливості використання процесу художнього конструювання як засобу в розвитку творчих здібностей учнів.

Ключові слова: творча діяльність, художнє конструювання, здібності, творчі 